\title{
The Effect of Social Media Networking Use in EFL Classrooms in Saudi Arabia: An Argumentative Review
}

\author{
Saleh Alrasheedi ${ }^{1}$ \\ ${ }^{1}$ Department of English, College of Education, Majmaah University, Majmaah, Saudi Arabia \\ Correspondence: Department of English, College of Education, Majmaah University, Majmaah 11952, Saudi \\ Arabia. E-mail: s.alresheed@mu.edu.sa
}

\author{
Received: October 3, 2019 Accepted: November 7, 2019 Online Published: December 28, 2019 \\ doi:10.5539/ijel.v10n1p241 URL: https://doi.org/10.5539/ijel.v10n1p241
}

\begin{abstract}
This study provides an argumentative literature review of the research done in the use of social media in EFL acquisition in Saudi Arabia since 2014. Starting from 455 sources, 15 articles were selected using predefined selection criteria. The documents were analyzed and coded using these classifications: participants, educational level, study design, SNS being reviewed, pedagogical practice, and learning impact. This information allowed identification of major educational outcomes related to the integration of social networking sites (SNSs) into English as Foreign Language (EFL) learning and teaching in Saudi Arabia. It also shed light on reservations and difficulties faced in integrating SNSs into the EFL acquisition classroom. The results of this literature review indicate the importance of adopting social networking sites in elementary and preparatory stages in Saudi Arabia. Additionally, there should be an interest in analyzing learners' and teachers' motivations and attitudes toward social networking sites.
\end{abstract}

Keywords: argumentative review, computer-mediated communication (CMC), English as foreign language (EFL), language learning, qualitative meta-analysis, Saudi Arabia, social networking sites

\section{Introduction}

Web 2.0 technologies and social media applications (blogs, wikis, podcasting, photo and video sharing, WhatsApp, Facebook, Twitter, etc.), have become an integrated part of English language learning worldwide (Shih, 2011). The government of Saudi Arabia has taken steps to integrate information technology with learning through computer-mediated communication (CMC). The next step in e-learning is the integration of social networking sites (SNSs) into learning, and specifically in English as Foreign Language (EFL) acquisition. However, a number of barriers exist (Al-Asmari \& Khan, 2014).

The current paper examines the use and influence of SNSs in the light of the rise of technology use in EFL contexts. Via an argumentative literature review of the research done in the use of social media in EFL acquisition in Saudi Arabia since 2014, I seek to answer the following research questions:

1) What are the main aims of these studies, and what methodologies are used to achieve them?

2) What are the major findings across the studies reviewed? Specifically:

a) In what contexts are SNSs utilized for EFL learning?

b) What learning outcomes are identified in these studies?

c) What opportunities do they identify?

d) What barriers do they identify?

3) What gaps in the research are revealed through these studies?

This argumentative review contributes to the existing literature by: (1) exploring the contributions of selected studies to the discourse around adopting SNSs in Saudi Arabia as a form of CALL; (2) developing a body of literature that establishes a viewpoint contrary to existing views (prevalent in Saudi Arabia) that SNSs are detrimental or unhelpful in EFL language learning; and (3) identifying research gaps and where further research should be carried out. 


\subsection{Definition of Terms}

Computer-mediated communication (CMC) is defined as discourse that takes place via the use of two or more electronic devices. Email and blogging are examples of asynchronous $\mathrm{CMC}$, while chat and instant messaging are common types of synchronous CMC. Asynchronous CMC is similar to traditional written communication, whereas synchronous CMC is analogous to spoken communication (Hirotani, 2009).

Social media are "forms of electronic communication (as Web sites for social networking and micro blogging) through which users create online communities to share information, ideas, personal messages, and other content (such as videos)" (Merriam-Webster Dictionary, 2019).

A social network site (SNS) is a networked website or application that allows people to: meet, collaborate, and share ideas, interests, and artifacts with one another via the internet.

\section{Context and Relevant Literature}

In Saudi Arabia, the prominence of English continues to increase and EFL is considered a major subject in the Saudi education system. According to Carfax Educational Projects (2016), "English is the only foreign language taught in Saudi schools as part of the mandatory curriculum and therefore enjoys a relatively high status" (p. 10). At the same time, SNSs such as Facebook, Twitter, YouTube, Instagram, and the like have gained tremendous popularity (Figure 1; Riyanto, 2013). For example, 40\% of Twitter users are located in the Middle East, with more than "210 million tweets each month," and in fact, Saudi Arabia is possibly the most dynamic user of social media in the Middle East (The Online Project, 2015). Hence, social networking has opened up new opportunities of communication and collaboration among teachers and students. Some EFL researchers are now recommending that Saudi teachers incorporate SNSs for instructional purposes in their classrooms (Ashiyan \& Salehi, 2017; Alkhatnai, 2019) and for continued learning beyond the classroom (Alfaki \& Alharthy, 2014).

\subsection{The World's Users of Social Networking Sites}

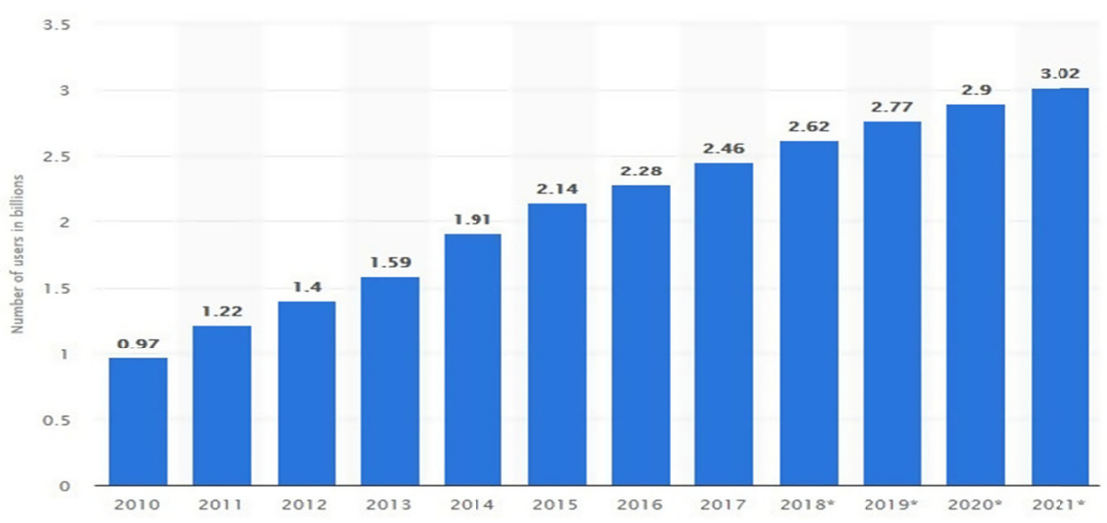

Figure 1. The world's users of SNSs in the last ten years (Clement, 2019)

It is noted from Figure 1 that the number of SNS users worldwide has tripled since 2010. It started with less than one billion and is expected to reach more than three billion by 2021. Half of the world's population uses social media, and this is for a variety of purposes, such as communication, business, and education. Therefore, it is difficult to ignore SNSs, as they have become an integral part of people's lives. 


\subsection{Major Social Networking Sites}

\section{The 21 most popular social media sites in 2019 Monthly active users (in millions)}
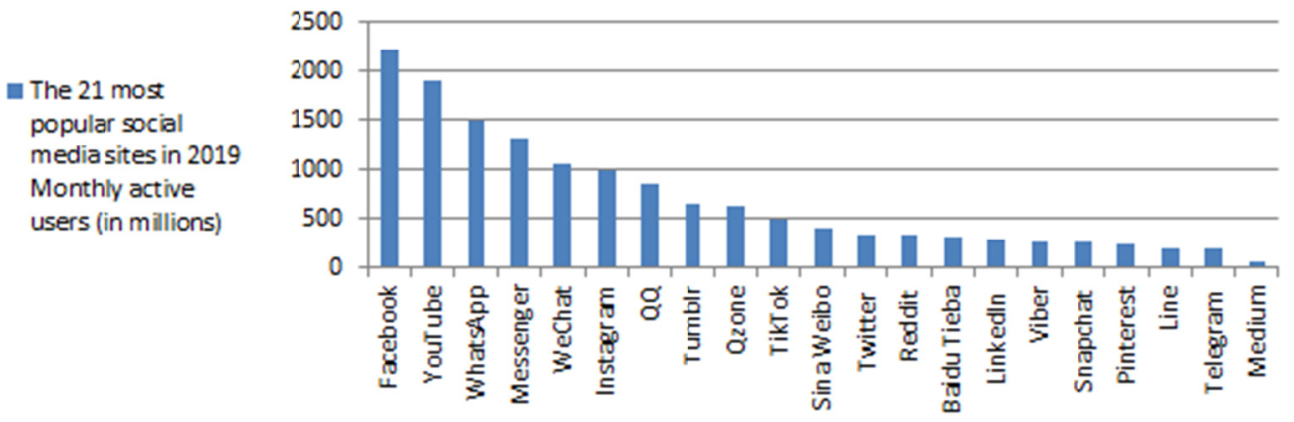

Figure 2. Number of monthly active users of the top 21 SNSs worldwide in 2018, in millions (Clement, 2019; Lua, 2019)

Facebook is the most-used SNS in the world, with more than two billion people (nearly one third of the world's population) using it every month. Additionally, more than 65 million businesses use Facebook Pages. YouTube is the second-largest SNS, with more than 1.9 billion users around the world. YouTube (owned by Google) is also often acknowledged as the second-largest search engine, after Google; as such, it has evident value in the field of teaching. WhatsApp comes third on this list with more than 1.5 billion users in 180 countries (Clement, 2019).

\subsection{Technology and EFL Learning in Saudi Arabia}

Since the appearance of Web 1.0 in the first decade of the 21 st century and then Web 2.0 technologies and social media applications, English language learning has been incorporating these technologies (Shih, 2011). Perhaps the most 'futuristic' such implementation has been through experimentation with language learning in virtual worlds (Warschauer \& Grimes, 2007). In the 2010s, we have seen increased use of tablets and smart phones, rapid expansion of streaming media, ubiquitous computing (including wearables such as watches), gamification, and increasing normalization - the last referring to a state where we are so used to technology we may stop thinking about it creatively.

Alfaki and Alharthy (2014) have remarked on the low quality of EFL learning in the Arabic-speaking countries in general; and despite the stated importance given to EFL and the facilities provided by the government for EFL learning (Almegran, Al-Yafei, \& Hashem, 2007), the quality of English teaching in Saudi Arabia remains substandard. Indeed, Carfax Educational Projects (2016) have rated Saudi learners' English language skill as among the poorest in the world. This leads to the inevitable conclusion that current EFL teaching and learning methodologies should be revised and improved. This change has already been spearheaded by e-learning technologies. The Saudi government has taken steps to integrate information technology with learning through both synchronous and asynchronous CMC (Albalawi, 2013; Al-Asmari \& Khan, 2014). However, the next step in e-learning is the integration of SNSs into learning, and specifically into EFL acquisition.

\subsection{Social Media for Education}

Technologies associated with social media are often debated within the broader context of Web 2.0, a term that came into prominent use near the end of 2004. Language educators have been quick to appropriate Web 2.0 technologies to facilitate participatory practices in language learning, guiding learners to individually or collaboratively generate content which can be posted, rapidly updated and continually revised (Warschauer, 2009). Consequently, over the past decade and a half, researchers have conducted various studies on the effects of SNSs on language learning. Many of these investigations report a mix of positive and negative influences (e.g., Bosch, 2009; Selwyn, 2009; Ahmed \& Qazi, 2011; Yunus, Salehi, \& Chenzi, 2012; Kamnoetsin, 2014; Mensah $\&$ Nizam, 2016), with the overall assessment being that whereas there are some benefits to be found, undesirable consequences may or do result. As one commentator mentioned, “... the majority of what is written by the general public on social media is not edited, supervised or checked to ensure that proper use of the English 
language is taken into consideration" (Foster, 2015) and hence, SNSs were seen as more useful for informal rather than formal learning (Kamnoetsin, 2014).

Numerous studies found negative effects of SNSs on language learning (e.g., González, 2003; Karpinski, 2009; Madge, Meek, Wellens, \& Hooley, 2009; Shih, 2011; Abbasova, 2016; Cabrera, 2018; Chepkemoi, Situma, \& Murunga, 2018). Many of these reported negative effects on study and writing techniques, including distraction from studies, decreased aptitude in grammar and spelling, and increased tendency to copy-paste content instead of creating original content (Cabrera, 2018), as well as declines in overall academic performance (Karpinski, 2009). Madge et al. (2009) indicated that SNSs may not be appropriate tools for formal teaching and learning activities.

\subsection{Pedagogical Implications for Social Network Sites}

Despite the possible pitfalls of SNS use in language learning, however, the fact remains that SNSs have become integral to the lives of young people the world over (Alfaki \& Alharthy, 2014; Ashiyan \& Salehi, 2017). Moreover, previous research has shown that learners "produce more language output in synchronous CMC discourse than in the face-to-face environment" (Hirotani, 2009, p. 414). Thus, the potential for harnessing the power of SNSs to improve learning outcomes is substantial, and merits further examination.

AlQahtani (2018) suggested the following pedagogical implications for SNS:

1) The use of social networks offers powerful information-sharing and collaborative opportunities for learners and learning.

2) Social networks can grant researchers and educationalists with ample evidence regarding the advantages offered by this particular method of teaching English.

3) A significant implication of this study is related to the effects of making learning public, rather than confining it within a protected community of learners.

4) Such a learning methodology through social networks would make students more motivated about the learning process.

5) The implementation of social networks into the educational process would be highly valued by students, as they find it to be a good learning/assessment tool.

6) Social networks provide individuals with a way of maintaining and strengthening social ties, which can be beneficial in both social and academic settings.

\section{Methodology}

The American Psychological Association's (APA) Journal Article Reporting Standards (JARS) describes qualitative meta-analysis as "a form of inquiry in which qualitative research findings about a process or experience are aggregated or integrated" and it "involves the interpretive aggregation of thematic findings rather than reanalysis of primary data" (Levitt et al., 2018, p. 40). An argumentative review is a type of qualitative meta-analysis that "examines literature selectively in order to support or refute an argument, $[\ldots]$ assumption, or philosophical problem already established in the literature. The purpose is to develop a body of literature that establishes a contrarian viewpoint" (Larabee, 2019). In the present research it refers to the selected types of literature that support the importance of adopting social networking sites in teaching English as a foreign language in Saudi Arabia.

A general search was conducted in July 2019 on the following five sites: ERIC (Education Resources Information Center), JSTOR, ProQuest, ScienceDirect, and SAGE Journals Online, with the term 'EFL in Saudi context' and yielded 454 studies. Of those, only 35 were relevant to SNS in EFL learning, and further analysis yielded only 14 studies that met all research criteria, as described below. In October 2019, one additional study that had been published in the interim was found serendipitously, bringing to 15 the total number of studies meeting the criteria.

\subsection{Research Criteria}

To be considered appropriate for this review, the studies have to fulfill the ensuing inclusion criteria:

- The study must be based in Saudi Arabia.

- The investigation must unequivocally address EFL learning or teaching and the use of SNSs as defined in this review.

- The article had to be published in a journal or conference proceedings between 2014 and 2019 (within 
five years prior to this review).

- The article must be written in English.

- The article must have an abstract. The abstract is used to select relevant papers during the argumentative review process.

\section{Analysis of Literature}

The review and analysis of the study sample takes a thematic approach, and groups the studies according to the SNSs explored in each. Data from the chosen studies were coded and extracted under the following variables: SNSs used (Table 1); study authors and year of publication; description of intervention (participants, timing, content); aims of the study; study design (quantitative/qualitative); key findings; and opportunities and barriers identified in using SNSs. The data are presented in Tables 1 through 6.

\subsection{Social Networking Sites (SNSS) as Focus of Study}

The majority of the 15 studies $(n=8,53.3 \%)$ investigated two or more SNSs simultaneously; however, a few studies investigated Twitter $(n=3,20 \%)$ and WhatsApp $(n=4,26.7 \%)$ in a standalone capacity (see Table 1$)$.

Table 1. SNS applications used in studies reviewed

\begin{tabular}{lll|}
\hline SNS applications used in study & Frequency & Percentage \\
\hline Twitter only & 3 & $20 \%$ \\
WhatsApp only & 4 & $26.7 \%$ \\
Twitter and WhatsApp & 1 & $6.7 \%$ \\
Facebook and Skype & 1 & $6.7 \%$ \\
More than two SNS applications & 6 & $40 \%$ \\
Total studies & 15 & $100 \%$ \\
\hline
\end{tabular}

Table 2. Research studies related to Twitter

\begin{tabular}{|c|c|c|c|c|c|}
\hline $\begin{array}{l}\text { Study authors } \\
\text { and date }\end{array}$ & $\begin{array}{l}\text { Participants and study } \\
\text { periods }\end{array}$ & Aims of the study & $\begin{array}{l}\text { Evaluation } \\
\text { methodology }\end{array}$ & Key findings & $\begin{array}{l}\text { Barriers to SNS } \\
\text { adoption }\end{array}$ \\
\hline (1) Said, 2015 & $\begin{array}{l}2 \text { English writing } \\
\text { classes (level four) of } \\
\text { female undergraduates } \\
\text { in Qassim University, } \\
\text { randomly assigned to } \\
\text { experimental and } \\
\text { control groups for a } \\
\text { period of eight weeks. }\end{array}$ & $\begin{array}{l}\text { Examining the effect } \\
\text { of twitter on EFL } \\
\text { writing and whether } \\
\text { Twitter has an } \\
\text { influence on: } \\
\text { concepts and } \\
\text { content, } \\
\text { organization, voice, } \\
\text { and style. }\end{array}$ & $\begin{array}{l}\text { This study } \\
\text { followed a } \\
\text { pre/post-test } \\
\text { experimental-cont } \\
\text { rol group design }\end{array}$ & $\begin{array}{l}\text { Twitter can have a positive effect on } \\
\text { improving students' writing skills. } \\
\text { Twitter online discussion occurred } \\
\text { both in and after class meeting. From } \\
\text { the instructor's observation, the } \\
\text { students in the experimental group } \\
\text { produced more tweets and wrote more } \\
\text { than the control group. }\end{array}$ & None discussed \\
\hline $\begin{array}{l}\text { (2) Allam, } \\
\text { Elyas, Bajnaid, } \\
\text { \& Rajab, } 2017\end{array}$ & $\begin{array}{l}50 \text { female preparatory } \\
\text { year students studying } \\
\text { EFL at the English } \\
\text { Language Institute. } \\
\text { The study included } 50 \\
\text { male and female } \\
\text { English learners who } \\
\text { were studying abroad. }\end{array}$ & $\begin{array}{l}\text { The study } \\
\text { investigated Saudi } \\
\text { learners' adaption of } \\
\text { Twitter and } \\
\text { employing it as an } \\
\text { English acquisition } \\
\text { tool and the different } \\
\text { attributes of each } \\
\text { adopter group using } \\
\text { Roger's Diffusion of } \\
\text { Innovation Theory. }\end{array}$ & $\begin{array}{l}\text { This is a } \\
\text { quantitative study } \\
\text { using a three-part } \\
\text { questionnaire. }\end{array}$ & $\begin{array}{l}\text { The rate of adoption was not high, } \\
\text { reaching only approximately } 43 \% \text { of } \\
\text { students who showed positive } \\
\text { perceptions of Twitter. The students } \\
\text { who reported a neutral or negative } \\
\text { opinion were either still not sure how } \\
\text { to use Twitter as a learning } \\
\text { instrument, or they might employ it } \\
\text { only under certain circumstances. }\end{array}$ & $\begin{array}{l}\text { Language } \\
\text { barrier, poor } \\
\text { internet } \\
\text { connectivity, and } \\
\text { lack of technical } \\
\text { knowledge }\end{array}$ \\
\hline $\begin{array}{l}\text { (3) Alsharidi, } \\
2018\end{array}$ & $\begin{array}{l}25 \text { female Saudi } \\
\text { students aged } 18 \text { to } 23 \\
\text { who spoke Arabic as } \\
\text { L1. They were at } \\
\text { different levels of } \\
\text { university education } \\
\text { and enrolled in a } \\
\text { variety of programs } \\
\text { offered by a local } \\
\text { health sciences uni- } \\
\text { versity for female } \\
\text { students. }\end{array}$ & $\begin{array}{l}\text { Examining whether } \\
\text { the use of Twitter as } \\
\text { a tool for English } \\
\text { practice is reflected } \\
\text { in the language } \\
\text { development of adult } \\
\text { female EFL learners } \\
\text { in Saudi Arabia. }\end{array}$ & $\begin{array}{l}\text { This study used a } \\
\text { mixed methods } \\
\text { approach, survey } \\
\text { questionnaire, and } \\
\text { semi-structured } \\
\text { interviews }\end{array}$ & $\begin{array}{l}\text { Twitter provides female Saudi EFL } \\
\text { learners the opportunity to behave and } \\
\text { think like active users of the English } \\
\text { language. The learners believe that } \\
\text { their use of Twitter to practice the } \\
\text { target language exposes them to } \\
\text { genuine contexts and audiences and } \\
\text { that exposure to social engagement } \\
\text { facilitates their language } \\
\text { development. Learning mostly occurs } \\
\text { in an informal setting that extends } \\
\text { beyond the confines of a classroom. }\end{array}$ & None discussed \\
\hline
\end{tabular}


Table 3. Research studies related to WhatsApp

\begin{tabular}{|c|c|c|c|c|c|}
\hline $\begin{array}{l}\text { Study authors } \\
\text { and date }\end{array}$ & Participants & Aims of the study & Evaluation methodology & Key findings & $\begin{array}{l}\text { Barriers to SNS } \\
\text { adoption }\end{array}$ \\
\hline (4) Fattah, 2015 & $\begin{array}{l}30 \text { second-year } \\
\text { college students in } \\
\text { the English } \\
\text { department of a } \\
\text { private university } \\
\text { in Saudi Arabia }\end{array}$ & $\begin{array}{l}\text { To determine the } \\
\text { efficacy of using } \\
\text { WhatsApp as a } \\
\text { mobile learning } \\
\text { technique to develop } \\
\text { students' writing } \\
\text { skills. }\end{array}$ & $\begin{array}{l}\text { The quasi-experimental } \\
\text { design was used in this } \\
\text { study and a pre/post-test } \\
\text { was used to evaluate } \\
\text { progress. }\end{array}$ & $\begin{array}{l}\text { WhatsApp technique } \\
\text { yielded significant } \\
\text { effects on students' } \\
\text { writing skills; i.e., the } \\
\text { experimental group } \\
\text { outperformed the } \\
\text { control group. }\end{array}$ & None discussed \\
\hline $\begin{array}{l}\text { (5) Al-shammari, } \\
\text { Parkes, \& } \\
\text { Adlington, } 2017\end{array}$ & $\begin{array}{l}49 \text { male students } \\
\text { enrolled in English } \\
\text { courses in the } \\
\text { preparatory year } \\
\text { and } 30 \text { male } \\
\text { faculty members } \\
\text { from the English } \\
\text { department }\end{array}$ & $\begin{array}{l}\text { To assess the } \\
\text { attitudes of } \\
\text { instructors and } \\
\text { students in the use of } \\
\text { WhatsApp for } \\
\text { informal learning. }\end{array}$ & $\begin{array}{l}\text { Focus groups and } \\
\text { thematic analysis }\end{array}$ & $\begin{array}{l}\text { Student and faculty } \\
\text { attitudes toward } \\
\text { WhatsApp were } \\
\text { positive, although some } \\
\text { faculty members } \\
\text { expressed reservations } \\
\text { toward its use. }\end{array}$ & $\begin{array}{l}\text { Misuse of WhatsApp } \\
\text { in the classroom, } \\
\text { mainly because } \\
\text { mobile devices and } \\
\text { uses were not } \\
\text { formally sanctioned } \\
\text { for use in classrooms. } \\
\text { Faculty members felt } \\
\text { that WhatsApp made } \\
\text { them more accessible } \\
\text { to students, especially } \\
\text { after hours. } \\
\text { Subsequently, the } \\
\text { anywhere-anytime } \\
\text { affordances of } \\
\text { WhatsApp in general } \\
\text { are seen more as a } \\
\text { burden than an asset. }\end{array}$ \\
\hline $\begin{array}{l}\text { (6) Alqasham, } \\
2018 \mathrm{a}\end{array}$ & $\begin{array}{l}25 \text { male students } \\
\text { studying in the first } \\
\text { and second levels } \\
\text { of the Preparatory } \\
\text { Year Program } \\
\text { (PYP) at the main } \\
\text { campus of Qassim } \\
\text { University }\end{array}$ & $\begin{array}{l}\text { To explore the } \\
\text { students' use of and } \\
\text { experiences with } \\
\text { WhatsApp outside } \\
\text { the classroom, and } \\
\text { how the app's use } \\
\text { could achieve } \\
\text { sustainability for } \\
\text { their English } \\
\text { learning. }\end{array}$ & $\begin{array}{l}\text { A mixed-methods } \\
\text { approach was adopted } \\
\text { for data collection and } \\
\text { included six instruments } \\
\text { consisting of initial and } \\
\text { post-project interviews, } \\
\text { focus group } \\
\text { participation, a } \\
\text { post-project } \\
\text { questionnaire, } \\
\text { observations, and } \\
\text { research log to gather } \\
\text { data from the students' } \\
\text { use of WhatsApp. }\end{array}$ & $\begin{array}{l}\text { WhatsApp's } \\
\text { implementation } \\
\text { demonstrated its } \\
\text { sustainability outside } \\
\text { the classroom for } \\
\text { English learning as } \\
\text { evident by the students' } \\
\text { continued use of } \\
\text { WhatsApp even after } \\
\text { the study ended by the } \\
\text { 12th week; in fact, they } \\
\text { continued to use it until } \\
\text { the end of the semester } \\
\text { (week 17). }\end{array}$ & $\begin{array}{l}\text { Misuse: } \\
\text { "Entertaining" } \\
\text { messages sent by } \\
\text { some students made } \\
\text { some others feel } \\
\text { uncomfortable. }\end{array}$ \\
\hline $\begin{array}{l}\text { (7) Alkhatnai, } \\
2019\end{array}$ & $\begin{array}{l}3 \text { teachers and } 15 \\
\text { English major } \\
\text { students at the } \\
\text { College of } \\
\text { Languages and } \\
\text { Translation at King } \\
\text { Saud University, } \\
\text { Riyadh }\end{array}$ & $\begin{array}{l}\text { To investigate the } \\
\text { views of Saudi } \\
\text { translation teachers } \\
\text { and students toward } \\
\text { using instant } \\
\text { messaging services } \\
\text { (e.g., WhatsApp) in } \\
\text { their translation } \\
\text { learning and teaching }\end{array}$ & $\begin{array}{l}\text { Teacher participants } \\
\text { were chosen who were } \\
\text { already using WhatsApp } \\
\text { as a teaching/ learning } \\
\text { resource. Teachers' and } \\
\text { students' utterances were } \\
\text { elicited via } \\
\text { semi-structured } \\
\text { interviews. Using a } \\
\text { qualitative research } \\
\text { method (content } \\
\text { analysis), utterances } \\
\text { were analyzed and pros } \\
\text { and cons of using } \\
\text { WhatsApp described. }\end{array}$ & $\begin{array}{l}\text { Teachers and students } \\
\text { had different reasons } \\
\text { for establishing chat } \\
\text { groups and for possible } \\
\text { uses of this technology; } \\
\text { some participants raised } \\
\text { technological and } \\
\text { instructional pitfalls but } \\
\text { many also reported } \\
\text { educational and social } \\
\text { gains; all agreed it was } \\
\text { effective for their } \\
\text { teaching and learning. }\end{array}$ & $\begin{array}{l}\text { 1) Heavy use of } \\
\text { abbreviated, } \\
\text { oversimplified } \\
\text { language can be } \\
\text { confusing to learners; } \\
\text { can also result in } \\
\text { inappropriate use in } \\
\text { situations where } \\
\text { formal language is } \\
\text { more appropriate. } \\
\text { 2) Potential technical } \\
\text { problems, e.g. } \\
\text { malfunctioning } \\
\text { phones or computers, } \\
\text { network issues, and } \\
\text { unreliable Internet } \\
\text { connection. }\end{array}$ \\
\hline
\end{tabular}


Table 4. Research studies related to Facebook and Skype

\begin{tabular}{|c|c|c|c|c|c|}
\hline $\begin{array}{l}\text { Study } \\
\text { authors and } \\
\text { date }\end{array}$ & $\begin{array}{l}\text { Participants and } \\
\text { study periods }\end{array}$ & Aims of the study & Evaluation methodology & Key findings & $\begin{array}{l}\text { Barriers to } \\
\text { SNS adoption }\end{array}$ \\
\hline $\begin{array}{l}\text { (8) Bataineh, } \\
2014\end{array}$ & $\begin{array}{l}40 \text { students in the } \\
\text { Department of } \\
\text { Languages and } \\
\text { Translation at } \\
\text { Taibah University, } \\
\text { registered for the } \\
\text { Writing II course in } \\
\text { the first semester of } \\
\text { the } 2012 \text { - } 2013 \\
\text { academic year }\end{array}$ & $\begin{array}{l}\text { This study aims to } \\
\text { explore the effect of using } \\
\text { social networking sites } \\
\text { and word processors on } \\
\text { the writing performance } \\
\text { of foreign language } \\
\text { students. The study looks } \\
\text { at individual components } \\
\text { of the writing process } \\
\text { (spelling, vocabulary, } \\
\text { content, organization, } \\
\text { punctuation, language } \\
\text { use, grammar, and } \\
\text { authenticity) to evaluate } \\
\text { the impact of technology } \\
\text { on specific aspects of } \\
\text { language mastery. }\end{array}$ & $\begin{array}{l}\text { Forty subjects were } \\
\text { divided into two sections: } \\
\text { Section One was } \\
\text { assigned as an } \\
\text { experimental group } \\
\text { (supported by Facebook } \\
\text { and Skype) and Section } \\
\text { Two was assigned as a } \\
\text { control group and was } \\
\text { asked to write their } \\
\text { essays with paper and } \\
\text { pencil. Facebook and } \\
\text { Skype accounts were } \\
\text { created for every student } \\
\text { in the experimental } \\
\text { group. Data was analyzed } \\
\text { from pre-test and } \\
\text { post-test results to } \\
\text { evaluate students' } \\
\text { learning. }\end{array}$ & $\begin{array}{l}\text { Students who } \\
\text { worked with } \\
\text { Facebook and Skype } \\
\text { showed a significant } \\
\text { improvement in } \\
\text { their writing skills } \\
\text { when compared to } \\
\text { the control group. }\end{array}$ & $\begin{array}{l}\text { None } \\
\text { discussed }\end{array}$ \\
\hline
\end{tabular}

Table 5. Research studies related to Twitter and WhatsApp

\begin{tabular}{|c|c|c|c|c|c|}
\hline $\begin{array}{l}\text { Study authors } \\
\text { and date }\end{array}$ & $\begin{array}{l}\text { Participants and } \\
\text { study periods }\end{array}$ & Aims of the study & $\begin{array}{l}\text { Evaluation } \\
\text { methodology }\end{array}$ & Key findings & $\begin{array}{l}\text { Barriers to SNS } \\
\text { adoption }\end{array}$ \\
\hline $\begin{array}{l}\text { (9) Alqasham, } \\
2018 b\end{array}$ & $\begin{array}{l}93 \text { English } \\
\text { language } \\
\text { teacher-trainees } \\
\text { and } 84 \text { PYP } \\
\text { students from } \\
\text { three different } \\
\text { colleges at Qassim } \\
\text { University; } 25 \\
\text { PYP students } \\
\text { throughout the } \\
\text { 12-week semester }\end{array}$ & $\begin{array}{l}\text { Understanding of the } \\
\text { ways the innovative } \\
\text { use of a virtual social } \\
\text { network can aid } \\
\text { students in and } \\
\text { outside the classroom } \\
\text { by allowing them to } \\
\text { practice and } \\
\text { collaborate in English } \\
\text { learning. }\end{array}$ & $\begin{array}{l}\text { A mixed-methods } \\
\text { approach for data } \\
\text { collection, divided } \\
\text { into two stages: one } \\
\text { designed to gather } \\
\text { background } \\
\text { information and } \\
\text { another for a } \\
\text { longitudinal study }\end{array}$ & $\begin{array}{l}\text { WhatsApp's } \\
\text { implementation was } \\
\text { sustainable, } \\
\text { continuing even } \\
\text { after the study } \\
\text { ended and until the } \\
\text { end of the semester. } \\
\text { Twitter's use failed } \\
\text { to be sustained } \\
\text { inside the classroom } \\
\text { beyond the ninth } \\
\text { week. }\end{array}$ & $\begin{array}{l}\text { Privacy concerns } \\
\text { in open platforms } \\
\text { such as Twitter and } \\
\text { Instagram. } \\
\text { Technical concerns } \\
\text { of connectivity and } \\
\text { users' adoption of } \\
\text { SNS. }\end{array}$ \\
\hline
\end{tabular}


Table 6. Research studies related to more than two apps

\begin{tabular}{|c|c|c|c|c|c|}
\hline $\begin{array}{l}\text { Study authors, } \\
\text { date, and social } \\
\text { media tools }\end{array}$ & $\begin{array}{l}\text { Participants and study } \\
\text { periods }\end{array}$ & Aims of the study & $\begin{array}{l}\text { Evaluation } \\
\text { methodology }\end{array}$ & Key findings & $\begin{array}{l}\text { Barriers to SNS } \\
\text { adoption }\end{array}$ \\
\hline $\begin{array}{l}\text { (10) Aifan, } \\
2015 \\
\text { (Facebook, } \\
\text { Twitter, } \\
\text { YouTube, } \\
\text { WhatsApp, } \\
\text { Wikipedia, and } \\
\text { Skype) }\end{array}$ & $\begin{array}{l}510 \text { students ( } 214 \text { male } \\
\text { and } 296 \text { female) from } \\
\text { King Abdul-Aziz } \\
\text { University, Jeddah, } \\
\text { participated in an } \\
\text { electronic survey. } 200 \\
\text { male and female Saudi } \\
\text { instructors participated in } \\
\text { the face-to-face interview. }\end{array}$ & $\begin{array}{l}\text { Investigates factors and } \\
\text { barriers affecting } \\
\text { attitudes toward using } \\
\text { social media, in order to } \\
\text { better understand the use } \\
\text { of social media in } \\
\text { learning by students and } \\
\text { teachers. }\end{array}$ & $\begin{array}{l}\text { A mixed-methods } \\
\text { study using } \\
\text { interviews for both } \\
\text { instructors } \\
\text { (face-to-face) and } \\
\text { students (online } \\
\text { interview). } \\
\text { Secondly, an } \\
\text { electronic survey of } \\
\text { students (online } \\
\text { questionnaire). }\end{array}$ & $\begin{array}{l}\text { Saudi students at King } \\
\text { Abdul-Aziz University } \\
\text { have positive attitudes } \\
\text { toward using social } \\
\text { media to support } \\
\text { learning. Faculty need to } \\
\text { develop their personal } \\
\text { learning of social media } \\
\text { tools in order to help } \\
\text { students benefit from } \\
\text { these technologies. }\end{array}$ & $\begin{array}{l}\text { Social media } \\
\text { contents can } \\
\text { mock the } \\
\text { students' } \\
\text { religion; } \\
\text { concerns about } \\
\text { privacy and } \\
\text { security issues } \\
\text { related to the use } \\
\text { of social media }\end{array}$ \\
\hline $\begin{array}{l}\text { (11) Kutbi, } \\
2015 \\
\text { (Facebook, } \\
\text { Twitter, and } \\
\text { YouTube) }\end{array}$ & $\begin{array}{l}25 \text { students from an } \\
\text { English course that is } \\
\text { taught using social media } \\
\text { at King Abdul-Aziz } \\
\text { University }\end{array}$ & $\begin{array}{l}\text { To determine how Saudi } \\
\text { female undergraduate } \\
\text { students perceive social } \\
\text { media in education. }\end{array}$ & $\begin{array}{l}\text { The study was } \\
\text { qualitative; a } \\
\text { questionnaire and an } \\
\text { interview were used. }\end{array}$ & $\begin{array}{l}\text { Most participants had } \\
\text { positive perceptions of } \\
\text { the use of social media in } \\
\text { education; however, the } \\
\text { majority used it mostly } \\
\text { for social and } \\
\text { entertainment purposes. }\end{array}$ & $\begin{array}{l}\text { Technical issues } \\
\text { such as } \\
\text { connectivity and } \\
\text { new adopters }\end{array}$ \\
\hline $\begin{array}{l}\text { (12) Allam \& } \\
\text { Elyas, } 2016 \\
\text { (SNS for } \\
\text { teaching) }\end{array}$ & $\begin{array}{l}75 \text { randomly chosen male } \\
\text { and female EFL teachers, } \\
\text { at two Saudi tertiary } \\
\text { institutions }\end{array}$ & $\begin{array}{l}\text { To look at the } \\
\text { perceptions of the EFL } \\
\text { teachers of using social } \\
\text { media as a pedagogical } \\
\text { approach in teaching } \\
\text { English as a second } \\
\text { language (L2) and what } \\
\text { are the factors that hinder } \\
\text { such adoption. }\end{array}$ & $\begin{array}{l}\text { Quantitative } \\
\text { methods using a } \\
\text { survey instrument to } \\
\text { gather descriptive } \\
\text { data; } 35 \text { male and } 40 \\
\text { female participants. } \\
\text { All the participants } \\
\text { work at two } \\
\text { different Saudi } \\
\text { universities in two } \\
\text { different cities. }\end{array}$ & $\begin{array}{l}\text { The majority expressed } \\
\text { reservations with regard } \\
\text { to the extent to which } \\
\text { social media can be } \\
\text { freely utilized in the EFL } \\
\text { classroom, despite the } \\
\text { acceptance of its } \\
\text { pedagogical value. }\end{array}$ & $\begin{array}{l}\text { Misuse of social } \\
\text { media, time } \\
\text { constraints, and } \\
\text { technical issues }\end{array}$ \\
\hline $\begin{array}{l}\text { (13) Alnujaidi, } \\
2017 \\
\text { (any SNS) }\end{array}$ & $\begin{array}{l}\text { Data collected from two } \\
\text { previous studies } \\
\text { administered by the } \\
\text { author: Study sample I } \\
\text { comprised EFL teachers } \\
\text { ( } N=107 \text {; male, female, } \\
\text { Saudi, and non-Saudi) in } \\
\text { several Saudi higher } \\
\text { education institutions. } \\
\text { Study sample II comprised } \\
\text { EFL students ( } N=103 \text {; } \\
\text { male, female, Saudi, and } \\
\text { non-Saudi) in several } \\
\text { Saudi higher education } \\
\text { institutions, at different } \\
\text { college levels, and with } \\
\text { various majors. }\end{array}$ & $\begin{array}{l}\text { The study reported here } \\
\text { explored the differences } \\
\text { between EFL teachers' } \\
\text { and students' } \\
\text { experiences, attitudes, } \\
\text { perceptions, and } \\
\text { expectations concerning } \\
\text { the effectiveness of SNS } \\
\text { in EFL. }\end{array}$ & $\begin{array}{l}\text { A survey } \\
\text { questionnaire. A } \\
\text { two-sample } t \text {-test } \\
\text { was employed to } \\
\text { investigate the } \\
\text { differences between } \\
\text { EFL teachers' and } \\
\text { students' experience, } \\
\text { attitudes, } \\
\text { perceptions, and } \\
\text { expectations toward } \\
\text { the effectiveness of } \\
\text { SNS in English } \\
\text { language teaching } \\
\text { and learning. }\end{array}$ & $\begin{array}{l}\text { The study also revealed } \\
\text { significant differences in } \\
\text { all four of these areas } \\
\text { between the findings for } \\
\text { teachers and those for } \\
\text { students: students had } \\
\text { more experience in using } \\
\text { SNS tools than teachers } \\
\text { did, and more positive } \\
\text { perceptions and } \\
\text { expectations. However, } \\
\text { teachers had more } \\
\text { positive attitudes toward } \\
\text { SNS than students did. }\end{array}$ & $\begin{array}{l}\text { Technical skills } \\
\text { and support }\end{array}$ \\
\hline $\begin{array}{l}\text { (14) Alshabeb } \\
\& \text { Almaqrn, } \\
2018 \\
\text { (any SNS) }\end{array}$ & $\begin{array}{l}102 \text { Saudi students at a } \\
\text { university in Riyadh; } \\
\text { students were both male } \\
\text { and female, studying } \\
\text { English at levels } 1 \text { to } 8 \text {. }\end{array}$ & $\begin{array}{l}\text { To discover whether the } \\
\text { students are currently } \\
\text { using social media } \\
\text { applications to enhance } \\
\text { their language skills and } \\
\text { what attitudes the } \\
\text { students hold toward the } \\
\text { use of social media via } \\
\text { mobile devices inside and } \\
\text { outside the classroom }\end{array}$ & $\begin{array}{l}\text { An exploratory } \\
\text { survey in which both } \\
\text { qualitative and } \\
\text { quantitative methods } \\
\text { tools were used }\end{array}$ & $\begin{array}{l}\text { Saudi EFL learners } \\
\text { showed positive attitudes } \\
\text { toward the usage of } \\
\text { social media applications } \\
\text { via mobile devices in } \\
\text { English classes. }\end{array}$ & $\begin{array}{l}\text { Lack of } \\
\text { knowledge of the } \\
\text { use of social } \\
\text { media } \\
\text { applica-tions in } \\
\text { English classes } \\
\text { for some students } \\
\text { or the teacher can } \\
\text { create negative } \\
\text { attitudes. }\end{array}$ \\
\hline $\begin{array}{l}\text { (15) Sharma, } \\
2019 \\
\text { (any SNS) }\end{array}$ & $\begin{array}{l}60 \text { Saudi EFL learners in } \\
\text { two semesters in the PYP } \\
\text { at Jazan University }\end{array}$ & $\begin{array}{l}\text { Investigate the } \\
\text { perspectives of Saudi } \\
\text { students on social media } \\
\text { use in order to promote } \\
\text { EFL learning and the } \\
\text { popular SM applications } \\
\text { in use. }\end{array}$ & $\begin{array}{l}\text { Quantitative study } \\
\text { using survey } \\
\text { questionnaire }\end{array}$ & $\begin{array}{l}\text { Students had a positive } \\
\text { attitude toward social } \\
\text { media use, feeling more } \\
\text { confident, competent, } \\
\text { and willing to } \\
\text { communicate in English } \\
\text { on social media. }\end{array}$ & $\begin{array}{l}\text { Saudi students } \\
\text { are concerned } \\
\text { about the } \\
\text { security of their } \\
\text { personal data and } \\
\text { private } \\
\text { information. }\end{array}$ \\
\hline
\end{tabular}




\subsection{Thematic Analysis}

\subsubsection{Study Aims and Design}

What are the main aims of these studies, and what methodologies are used to achieve them?

The main aims of the included studies were to promote understanding of the measurable effect of SNS in education $(n=7,46.7 \%)$, and/or to assess the attitudes of either or both teachers and students $(n=12,80 \%)$ regarding using SNS for educational purposes.

Study design and instrumentation varied in accordance with the stated aims and the characteristics of the study population (see section 4.2.2). Quantitative studies $(n=4,26.7 \%)$ used electronic surveys to collect data on attitudes toward SNS and adoption rate/stage; qualitative studies $(n=3,20 \%)$ used focus groups/interviews to assess attitudes and usage of SNS for learning; quasi-experimental studies $(n=3,20 \%)$ conducted pre- and post-tests to measure learning efficacies with SNSs as EFL tools; mixed-methods studies $(n=5,33.33 \%)$ used multiple instruments for data collection to assess attitudes and efficacies of SNSs in EFL learning and teaching.

\subsubsection{Study Participants and Educational Level}

Most of the studies $(n=9,60 \%)$ involved undergraduate students only, whereas a single study $(n=1,7.1 \%)$ focused on teachers only, exploring their perceptions and attitudes to SNSs in learning. One third of the studies $(n=5,33.3 \%)$ included both students and teachers. All of the studies $(n=15,100 \%)$ were conducted in higher educational institutions and universities in Saudi Arabia. No studies were found on SNS use in primary or middle schools in Saudi Arabia.

\section{Key Findings}

\section{What are the major findings across the studies reviewed?}

In what contexts are SNSs utilized for EFL learning? Popular teaching interventions included creating class-specific chat groups or 'pages' where teachers/students post assignments, queries, and responses, both in and outside the classroom. Such groups were created on Facebook, Skype, WhatsApp, and Twitter. These interactions take place in both classroom and non-classroom contexts.

What learning outcomes are identified in these studies? Most of the studies found a measurable and positive effect on students' writing (in terms of both quality and volume produced: Bataineh, 2014; Fattah, 2015; Said, 2015; Alsharidi, 2018); and comprehension of EFL (based on tests administered by researchers). WhatsApp and Twitter were found to be useful in supporting English language learning/teaching and are in fact the most popular SNSs in Saudi Arabia (Alsharidi, 2018; Fattah, 2015).

What opportunities do they identify? The investigation of attitudes toward using SNS in education showed mixed results. Students and teachers alike were enthusiastic adopters of SNS for social purposes. Nearly all students in the studies in this review expressed positive perceptions about using SNSs in education, although most used it mainly for socializing. Aifan's (2015) study involving the use of Facebook, Twitter, YouTube, WhatsApp, Wikipedia, and Skype found that learners are already well-versed on these sites, so teachers need to develop their personal learning of social media tools so as to "catch up" to where their learners are, in order for both students and teachers to benefit from the educational opportunities afforded by these technologies.

What barriers do they identify? While accepting its theoretical and pedagogic value, learners and teachers alike expressed reservations about practical applications of SNS in the educational context, Notable exceptions were three students who saw no advantages to using SNS in formal learning. These were two students in Alkhatnai's (2019) study and one in Kutbi's (2015) study: the former listed drawbacks such as deterioration of classroom dynamics (lack of in-class interaction, reduction in teacher's authority), over-reliance on SNS by students, and lack of clear classification of information (Alkhatnai, 2019, p. 103); the latter was against the use of SNS as she was a first-time user and because she did not have access to the internet at her home (Kutbi, 2015, p. 74). Furthermore, some students were resentful of the perceived disrespect of religious values expressed on SNSs (Aifan, 2015) and some disapproved of content deemed inappropriate (Alqasham, 2018a). Teachers were apprehensive of using SNS in the classroom due to fear of distraction (Alshammari et al., 2017; Allam \& Elyas, 2016), although they did acknowledge their pedagogical value. There were common concerns about privacy and security (expressed in 4 of the studies, 26.7\%; Aifan, 2015), technical issues including internet connectivity, not enough memory space on the device, and lack of technical know-how (7, 46.7\%; Alshammari et al., 2017; Alkhatnai, 2019), as well as misuse (5,33.3\%; Kutbi, 2015; Alkhatnai, 2019) of various SNSs.

\section{Discussion}

As stated earlier, the aim of this research was to investigate the use of SNS to support EFL learning and teaching 
by examining the current research trends. 15 studies were selected for review; however, the quality of research was not very high, as rigorous trials were lacking. Only three (Said, 2015 [Table 2]; Bataineh, 2014 [Table 4]; Fattah, 2015 [Table 3]) quasi-experimental studies $(n=3,20 \%)$ focused on the effect of SNS on writing skills. All three studies reported a marked improvement in the experimental group's writing skills compared to the control group using traditional study methods. Thirteen studies $(92.8 \%)$ found positive outcomes and attitudes toward the use of SNS in EFL learning and teaching. Moreover, Alqasham (2018a; Table 3) found that WhatsApp allows audio, visual, and chat features, as well as affording more privacy to students, and is more sustainable.

Most of the studies $(n=12,80 \%)$ examined attitudes and perceptions toward the use of SNS in learning. Where participants included teachers (Aifan, 2015; Allam \& Elyas, 2016; Alnujaidi, 2017 [Table 6]; Alshammari et al., 2017 [Table 3]; Alqasham, 2018b [Table 5]), the researchers mainly focused on reactions to teaching interventions. Students were generally enthusiastic in their adoption of SNSs, as evident in Table 6 (Aifan, 2015; Kutbi, 2015; Alnujaidi, 2017; Alshabeb \& Almaqrn, 2018; Sharma, 2019). Twitter and WhatsApp were especially popular applications (Alsharidi, 2018 [Table 2]; Alshammari et al., 2017; Alkhatnai, 2019 [Table 3]; Alqasham, 2018a \& 2018b [Tables 3 \& 5]).

Overall, these results, showing improvements in L2 skills combined with a mixture of positive and ambivalent attitudes to SNS use in language learning, reflected results from similar studies carried out in other parts of the world (Bosch, 2009; Selwyn, 2009; Ahmed \& Qazi, 2011; Yunus, Salehi, \& Chenzi, 2012; Kamnoetsin, 2014; Mensah \& Nizam, 2016) and in other Arabic-speaking countries (Alfaki \& Alharthy, 2014).

Notably, no study reported $100 \%$ positive response to SNS incorporation in education. Some students said that SNSs unfavorably influenced their writing skills due to the shortened styles popular on SNSs (AlQahtani, 2018). As observed by Alkhatnai (2016), almost a third of the students in King Saud University do not use SNSs due to a variety of factors (limited acccess and/or knowledge, social or economic reasons). He notes that "simply living in a technology rich environment does not immediately entail knowing how to employ this technology optimally to enhance learning and progressing" (Alkhatnai, 2016, p. 477). Alkhatnai (2016) noted that despite the high acceptance rate, some students are either opposed to or apprehensive of using SNSs due to technical issues (43\%) or for socio-religious reasons (28.7\%). In fact, there are two opposing results where one study found $84 \%$ of students in favour of using Twitter as a learning tool (Kutbi, 2015) while another reported that only $43 \%$ were comfortable using it for that purpose (Allam, Elyas, Bajnaid, \& Rajab, 2017).

Some students and teachers also had reservations about privacy, security, and inappropriate content on these sites (Aifan, 2015; Alnujaidi, 2017). These are common concerns associated with SNSs, not limited to education but to its use in general. Another concern is the lack of any formal guidelines or policy on using SNS in the classroom. Teachers also complained that its $24 / 7$ availability could be a nuisance and that too much familiarity impaired teacher-student relations (Alnujaidi, 2017; Alshabeb \& Almaqrn, 2018; Sharma, 2019).

Teachers had a more cautiously positive approach, with all agreeing to the efficacies of social networking in pedagogical practice, but with reservations about its applicability due to technical problems of internet connectivity and unfamiliarity with using SNS applications. One study (Allam \& Elyas, 2016), specifically based only on teachers' attitudes, found a negative response to SNS use in the classroom, while another study (Alnujaidi, 2017) found teachers' attitudes to SNS for learning were more positive than students' attitudes. This contrast, as well as the one aforementioned in students' adoption of Twitter, indicates a need for more rigorous and reliable investigations into attitudes toward and use of social media in EFL acquisition.

One theme that kept recurring among the attitudinal surveys was the influence of cultural or social norms. Al-Gahtani, Hubona, and Wang (2007) found that in the context of Saudi Arabia, cultural norms affect the rate and level of technology adoption. Indeed, Al Omoush, Yaseen, and Alma'aitah (2012) reported that the attitudes of young people from Arab countries regarding adoption/use of SNSs "are still influenced by the cultural values of [their] Arab nation" (p. 2387). The studies in the present literature review did not include cultural models in their analysis, but it seems clear from the aggregate of findings that culture is a factor that ought to be taken into account in research of this nature.

\subsection{Conclusion and Implications}

The EFL learning environment has developed various pedagogical practices that integrate SNSs for language acquisition; for example, dedicated Twitter handles/hashtags, WhatsApp groups, Facebook pages, Skype, and so on. These social interactions take place in both classroom and non-classroom contexts, generating a blended learning environment that supports situated and ubiquitous EFL acquisition. Opportunities exist for further development and integration of SNS in language learning in Saudi Arabia. 
However, as reported in the studies reviewed, there are still many barriers to address, including technical issues, security, social norms, and formal guidelines. One of the difficulties that teachers and some students face is a lack of training in how to use SNSs. These issues are not insurmountable and can be easily addressed by providing foundational training courses in ICT/SNS for both teachers and students, along with better hardware and technical support to educational institutions, and establishing formal guidelines and protocols for SNS in educational use, as seen in Kutbi (2015).

\subsection{Limitations and Suggestions for Future Study}

What gaps in the research are revealed through these studies? There is great need for more extensive, rigorous, and reliable research in this field as it is still in its nascent form in Saudi Arabia. As found in this review, there are many inconsistencies in research findings on attitudes and adoption of SNS in education by teachers and students. Further, research should also focus, via randomized controlled trials, on the use of SNS as a CALL tool not just for writing, but for other aspects of language acquisition such as reading, comprehension, and fluency in verbal communication. Finally, it is important to include social and cultural norms as factors in future studies.

\section{Acknowledgement}

The author would like to thank the Deanship of Scientific Research at Majmaah University for supporting this work under project number (R-1441-48).

\section{References}

Abbasova, M. (2016, August). The impact of social networks on the students' English language in Azerbaijan. International Multidisciplinary Scientific Conferences on Social Sciences and Arts, 3. Albena, Bulgaria. Retrieved from https://www.researchgate.net/publication/307967123_The_Impact_of_Social_Networks_on_the_Students' English_Language_in_Azerbaijan

Ahmed, I., \& Qazi, T. F. (2011). A look out for academic impacts of social networking sites: A student-based perspective. African Journal of Business Management, 5(12), 5022-5031.

Aifan, H. A. (2015). Saudi Students' attitudes toward using social media to support learning. Unpublished doctoral thesis, University of Kansas. Retrieved May 20, 2019, from https://kuscholarworks.ku.edu/bitstream/handle/1808/19498/Aifan_ku_0099D_13943_DATA_1.pdf

Al-Asmari, A. M., \& Khan, M. S. (2014). E-learning in Saudi Arabia: Past, present and future. Near and Middle Eastern Journal of Research in Education, 2014(2), 1-11. https://doi.org/10.5339/nmejre.2014.2

Albalawi, M. S. (2013). Web-based instructions: An assessment of preparedness of conventional universities in Saudi Arabia (Chapter 18). In K. P. Mehdi (Ed.), Cases on assessment and evaluation in education (pp. 415-449). Hershey, PA: IGI Global. https://doi.org/10.4018/978-1-4666-2621-8.ch018

Alfaki, I. M., \& Alharthy, K. (2014). Towards a digital world: Using social networks to promote learner's language. American International Journal of Contemporary Research, 4(10), 105-114. Retrieved from http://www.aijcrnet.com/journals/Vol_4_No_10_October_2014/13.pdf

Al-Gahtani, S. S., Hubona, G. S., \& Wang, J. (2007). Information Technology (IT) in Saudi Arabia: Culture and the acceptance and use of IT. Information \& Management, 44, 681-691. https://doi.org/10.1016/j.im.2007.09.002

Alkhatnai, M. (2016). Utilization of social networks among Saudi EFL Learners: Trends and uses. European Scientific Journal, 12(35), 464-482. https://doi.org/10.19044/esj.2016.v12n35p464

Alkhatnai, M. (2019). Instant mobile messaging (WhatsApp) and teaching translation: views elicited from Saudi translation teachers and students. International Journal of English Linguistics, 9(5), 98-106. https://doi.org/10.5539/ijel.v9n5p98

Allam, M., \& Elyas, T. (2016). Perceptions of using social media as an ELT tool among EFL teachers in the Saudi context. English Language Teaching, 9(7), 1-9. https://doi.org/10.5539/elt.v9n7p1

Allam, M., Elyas, T., Bajnaid, A., \& Rajab, H. (2017). Using Twitter as an ELT tool in the Saudi EFL context. International Journal of Linguistics, 9(5), 41-63. https://doi.org/10.5296/ijl.v9i5.11813

Almegran, A. M. A., Al-Yafei, A., \& Hashem, A. (2007). Pilot nationwide e-learning provision in the Kingdom of Saudi Arabia: Issues and challenges. Paper presented at the Twenty-first AAOU Annual Conference, Kuala Lumpur, 29-31 October 2007. http://library.oum.edu.my/repository/13/ 
Alnujaidi, S. (2017). Effects of social networking sites on EFL teachers and students. International Journal of English Language Teaching, 5(1), 1-14. Retrieved from https://www.eajournals.org/journals/international-journal-of-english-language-teaching-ijelt/vol-5-issue-1-ja nuary-2017/effects-social-networking-sites-efl-teachers-students/

Al Omoush, K., Yaseen, S., \& Alma'aitah, M. A. (2012). The impact of Arab cultural values on online social networking: The case of Facebook. Computers in Human Behavior, 28, 2387-2399. https://doi.org/10.1016/j.chb.2012.07.010

AlQahtani, N. A. (2018). The effect of social networks on the improvement of Saudi EFL students. Journal of Humanities and Social Sciences, 8(2), 137-150. https://doi.org/10.26389/AJSRP.N130618

Alqasham, F. H. (2018a). Exploring Saudi EFL learners' agency toward the use of WhatsApp for English learning at Qassim University. International Journal of Linguistics, 10(6), 10-43. https://doi.org/10.5296/ijl.v10i6.13857

Alqasham, F. (2018b). Virtual social network-mediated English language learning in a Saudi tertiary EFL context: Innovation and agency. $\mathrm{PhD}$ thesis, Massey University, Palmerston North, New Zealand. https://doi.org/10.13140/RG.2.2.23235.66081/1

Alshabeb, A. M., \& Almaqrn, R. K. (2018). A study of EFL Saudi students' use of mobile social media applications for learning. Arab World English Journal (Special Issue on CALL), 4, 214-226. https://doi.org/10.24093/awej/call4.17

Alshammari, R., Parkes, M., \& Adlington, R. (2017). Using WhatsApp in EFL instruction with Saudi Arabian university students. Arab World English Journal, 8(4), 68-84. https://doi.org/10.2139/ssrn.3094526

Alsharidi, N. K. (2018). The use of Twitter amongst female Saudi EFL learners. International Journal of Applied Linguistics \& English Literature, 7(4), 198-205. https://doi.org/10.7575/aiac.ijalel.v.7n.4p.198

Ashiyan, Z., \& Salehi, H. (2017). A comparison of male and female learners' English collocation learning through using WhatsApp. International Journal of Research Studies in Educational Technology, 6(1), 2542. https://doi.org/10.5861/ijrset.2016.1615

Bataineh, A. M. (2014). The effect of text chat assisted with word processors on Saudi English major students' writing accuracy and productivity of authentic texts. International Journal of Emerging Technologies in Learning, 9(9), 32-40. https://doi.org/10.3991/ijet.v9i9.4119

Bosch, T. E. (2009). Using online social networking for teaching and learning: Facebook use at the University of Cape Town. Communication: South African Journal for Communication Theory and Research, 35(2), 185200. https://doi.org/10.1080/02500160903250648

Cabrera, L. (2018). Impact of social media in English language learning: Utilizing S.W.O.T analysis (pp. 1-33). [Report.] Department of Education, Mimaropa Region, Philippines. Retrieved from https://www.researchgate.net/publication/327822150_impact_of_social_media_in_english_language_learni ng_utilizing_SWOT_analysis

Carfax Educational Projects. (2016). English Language Market Reports: Gulf States - Saudi Arabia: A report prepared for the UK's English language sector. UK: British Council. Retrieved from http://www.carfax-education.com/news/category/carfax-education/

Chepkemoi, K. C., Situma, J., \& Murunga, F. (2018). Influence of Facebook social-media usage on students' spellings in English written assignments in public day secondary schools in Eldoret North Sub-County. International Journal of Academic Research in Business and Social Sciences, 8(8), 159-171. https://doi.org/10.6007/IJARBSS/v8-i8/4456

Clement, J. (2019, July 23). Number of social media users worldwide 2010-2021. Retrieved from https://www.statista.com/statistics/278414/number-of-worldwide-social-network-users/

Fattah, S. F. (2015). The effectiveness of using WhatsApp Messenger as one of mobile learning techniques to develop students' writing skills. Journal of Education and Practice, 6(32), 115-127. https://iiste.org/Journals/index.php/JEP/article/view/27324

Foster, F. (2015). How is social media changing the English language? Language Services Direct [Online article]. Retrieved from https://www.languageservicesdirect.co.uk/social-media-changing-english-language/

González, D. (2003). Teaching and learning through chat: A taxonomy of educational chat for EFL/ESL. Teaching English with Technology, 3(4), 57-69. Retrieved from 
http://cejsh.icm.edu.pl/cejsh/element/bwmeta1.element.desklight-176e6886-2cb5-4ec2-b202-5323a4d89ed0

Hirotani, M. (2009). Synchronous versus asynchronous CMC and transfer to Japanese oral performance. CALICO Journal, 26(2), 413-438. https://doi.org/10.1558/cj.v26i2.413-438

Kamnoetsin, T. (2014). Social media use: A critical analysis of Facebook. Impact on collegiate EFL students' English writing in Thailand. Unpublished PhD dissertation, Seton Hall University Dissertations and Theses (ETDs). 2059. Retrieved from https://scholarship.shu.edu/dissertations/2059

Karpinski A. (2009). A description of Facebook use and academic performance among undergraduate and graduate students (pp. 1-19). Proceedings of the Annual Meeting of the American Educational Research Association. San Diego, CA: American National Research Association.

Kutbi, A. I. (2015). How undergraduate female students in the Kingdom of Saudi Arabia perceive social media as a learning tool: An exploratory study. Unpublished master's thesis, University of Windsor, Ontario, Canada. Retrieved May 20, 2019, from Electronic Theses and Dissertations https://scholar.uwindsor.ca/etd/5290

Larabee, R. (2019). The literature review. USC Libraries Research Guides [Online guide]. Retrieved from https://libguides.usc.edu/c.php?g=234974\&p=1559473

Levitt, H. M., Bamberg, M., Creswell, J. W., Frost, D. M., Josselson, R., \& Suárez-Orozco, C. (2018). Journal article reporting standards for qualitative primary, qualitative meta-analytic, and mixed methods research in psychology. The APA Publications and Communications Board Task Force report American Psychologist, 73(1), 26-46. https://doi.org/10.1037/amp0000151

Lua, A. (2019). 21 Top social media sites to consider for your brand. Buffer. Retrieved from https://buffer.com/library/social-media-sites on 07/23/2019

Madge, C., Meek, J., Wellens, J., \& Hooley, T. (2009). Facebook, social integration and informal learning at university: 'It is more for socialising and talking to friends about work than for actually doing work.' Learning, Media and Technology, 34(2), 141-155. https://doi.org/10.1080/17439880902923606

Mensah, S. O., \& Nizam, I. (2016). The impact of social media on students' academic performance-A case of Malaysia tertiary institution. International Journal of Education, Learning \& Training, 1, 14-21. https://doi.org/10.24924/ijelt/2016.11/v1.iss1/14.21

Merriam-Webster. (2019). Social media. Retrieved May 23, 2019, from Webster Online https://www.merriam-webster.com/dictionary/social\%20media

Riyanto, A. (2013, June 23). English language learning using 'WhatsApp' application. Retrieved May 23, 2019, from Akhmad

Riyanto https://akhmadriyantoblog.wordpress.com/2013/07/21/english-language-learning-using-whatsapp-applicatio $\mathrm{n} /$

Said, M. A. (2015). The effect of Twitter on developing writing skill in English as a foreign language. Arab World English Journal (Special Issue on CALL), 2, 134-149. https://doi.org/10.2139/ssrn.2843985

Selwyn, N. (2009). The digital native - myth and reality. Aslib Proceedings: New Information Perspectives, 61(4), 364-379. https://doi.org/10.1108/00012530910973776

Sharma, V. (2019). Saudi students' perspective on social media usage to promote EFL learning. International Journal of Linguistics, Literature and Translation, 2(1), 129-139.

Shih, R.-C. (2011). Can Web 2.0 technology assist college students in learning English writing? Integrating Facebook and peer assessment with blended learning. Australasian Journal of Educational Technology, 27(5), 829-845. https://doi.org/10.14742/ajet.934

The Online Project. (2015). Reintroducing social Saudis: How Saudi's social media behaviour changed over the past two years. Retrieved May 20, 2019, from The Online Project http://theonlineproject.me/files/reports/Reintroducing_Social_Saudis_English.pdf

Warschauer, M. (2009). 'Foreword'. In M. Thomas (Ed.), Handbook of research on Web 2.0 and second language learning. Hershey, PA: Information Science Reference.

Warschauer, M., \& Grimes, D. (2007). Audience, authorship, and artefact: The emergent semiotics of Web 2.0. Annual Review of Applied Linguistics, 27, 1-23. 1 https://doi.org/10.1017/S0267190508070013 
Yunus, M., Salehi, H., \& Chenzi, C. (2012). Integrating social networking tools into ESL writing classroom: Strengths and weaknesses. English Language Teaching, 5(8), 42-48. https://doi.org/10.5539/elt.v5n8p42

\section{Copyrights}

Copyright for this article is retained by the author, with first publication rights granted to the journal.

This is an open-access article distributed under the terms and conditions of the Creative Commons Attribution license (http://creativecommons.org/licenses/by/4.0/). 